University of Nebraska - Lincoln

DigitalCommons@University of Nebraska - Lincoln

Faculty Publications: Agricultural Leadership, Education \& Communication Department
Agricultural Leadership, Education \& Communication Department

$1-1-2004$

\title{
The Impact of Character Education Curricula on Youth Educators
}

\author{
Kristyn Harms \\ Norris High School, Firth, Nebraska, kristyn.jones@nsdtitans.org \\ Susan Fritz \\ University of Nebraska - Lincoln, sfritz1@unl.edu \\ S. Kay Rockwell \\ University of Nebraska - Lincoln, krockwell1@unl.edu
}

Follow this and additional works at: https://digitalcommons.unl.edu/aglecfacpub

Part of the Other Public Affairs, Public Policy and Public Administration Commons

\begin{abstract}
Harms, Kristyn; Fritz, Susan; and Rockwell, S. Kay, "The Impact of Character Education Curricula on Youth Educators" (2004). Faculty Publications: Agricultural Leadership, Education \& Communication Department. 29.

https://digitalcommons.unl.edu/aglecfacpub/29
\end{abstract}

This Article is brought to you for free and open access by the Agricultural Leadership, Education \& Communication Department at DigitalCommons@University of Nebraska - Lincoln. It has been accepted for inclusion in Faculty Publications: Agricultural Leadership, Education \& Communication Department by an authorized administrator of DigitalCommons@University of Nebraska - Lincoln. 


\title{
The Impact of Character Education Curricula on Youth Educators
}

\author{
Kristyn Marie Harms, M.S. \\ Secondary Agricultural Educator \\ Norris High School \\ Firth, Nebraska \\ kristyn.harms@norris160.org \\ Dr. Susan Fritz \\ Professor \\ Department of Agricultural Leadership, Education, and Communication \\ University of Nebraska \\ Lincoln, Nebraska \\ sfritz1@unl.edu \\ Dr. S. Kay Rockwell \\ Professor \\ Department of Agricultural Leadership, Education and Communication \\ University of Nebraska \\ Lincoln, Nebraska \\ krockwell1@unl.edu
}

\begin{abstract}
The purpose of this study was to determine degrees of internalization of character traits across two groups (K-12 teachers and Extension staff) with varying years of participation in character education professional and program development activities. An online survey was developed to collect data describing the 109 respondents, the extent of their character education professional and program development activities, and their degrees of internalization and behavioral change. Post-then-pre data comparisons revealed significant levels of change in behaviors, including considering other peoples' feelings and resolving conflict in a peaceful manner. All post-then-pre data demonstrated that respondents at least frequently lived their lives in accordance with the post-then-pre statements. Recommendations for future research included: marketing character education professional development opportunities to a broader audience; and increasing ongoing and intensive multicultural training of Cooperative Extension staff.
\end{abstract}

\section{Introduction}

Throughout a lifetime, one experiences numerous opportunities in which an individual's character is developed. Through successes and failures, a moralistic 
foundation is then created. As one continues to experience life, additional values and character traits are implemented to strengthen this foundation. The foundation is continually relied upon as a background for important decision-making processes. However, these processes can warp due to outside, unethical influences. A close examination of current ethical societal trends indicates this warping is likely to be happening with increasing frequency. These trends as well as state statutes, the history of character education, and adult learning strategies provide the framework for this study of the internalization of ethical values by those teaching character education.

\section{Ethical Trends in Society}

Though evidence of crime and violence grab headlines, collective morality is also revealed by a willingness to lie and cheat. In a recent survey of more than 15,000 high school and middle school students conducted by the Josephson Institute of Ethics (2001a):

- $39 \%$ of middle school and 36\% of high school students do not feel safe at school.

- $37 \%$ of middle school and $43 \%$ of high school boys "believe it is okay to hit or threaten someone who makes them angry."

- $21 \%$ of high school and $15 \%$ of middle school boys "took a weapon to school at least once in the past year.”

- $60 \%$ of high school and $31 \%$ of middle school boys believe they could obtain a gun if necessary.

- $69 \%$ of high school and $27 \%$ of middle school boys believe they could obtain drugs if they so desired.

- $19 \%$ of high school and $9 \%$ of middle school boys "admit they were drunk at school at least once in the past year."

\section{State Statutes and Character Education}

The picture painted by these findings suggests the need for a commitment toward enhancing the value individuals, as a society, place on traits such as respect and trustworthiness. However, throughout history, lawmakers consistently refer to the importance of character education in all age groups. Even though the Constitution of the United States of America fails to mention character education, one of its early writers, Benjamin Franklin, noted the importance of character education among youth in his Proposals Relating to the Education of Youth in Pennsylvania: "On historical questions of right and wrong, justice and injustice, will naturally 
arise, and may be put to youth, which they may debate in conversation and in writing” (Nebraska Department of Education, 2002).

The United States' dedication to character education is further demonstrated in Nebraska law. In 1927, State Senator Allen S. Stinson of Knox County introduced legislation making reference to the necessity of character education in public and private school systems. More than 75 years later, the State of Nebraska continues to mandate the teaching of character education in all school systems grades K-12. According to Rule 21 of the Nebraska Department of Education (2000), in order to be issued a Nebraska Teaching Certificate, one must complete an approved human relations training course from a qualifying institution of higher education. The purpose of human relations training is to educate teachers in the areas of living and teaching in a pluralistic society and dealing with diversity issues (i.e., sexism, racism, prejudice, and discrimination). This diversity training aids K-12 educators in teaching character education to a pluralistic environment, thus presenting the opportunity to enact all Nebraska character education statutes.

Nebraska laws suggest the need for an increased emphasis on character training. Societal trends suggest the need for a commitment toward enhancing the value individuals place on traits such as trustworthiness and respect. It also suggests the need for an increased emphasis on character training. No longer can society rely on families to be the only, or even the primary, force in shaping the character of children. In the 1995 Survey on the Advancement of Teaching sponsored by the Carnegie Foundation, 70\% of the U.S. parents questioned agreed that the family has the primary responsibility for developing values in children (Boyer, 1995). While U.S. families may strongly believe character education should occur at home, given the crime, violence and deception statistics, it is evidence that this "in home" approach needs support from other entities.

\section{History of Character Education}

The teaching of ethics and moral development has long been an interest of educators. Character education was often associated with education in general. Throughout history, the two goals of education were to help people become smart and to help them become good (Lickona, 1997). Acting on that belief, schools tackled character education through discipline, the teacher's example, and the daily school curriculum. The Bible was the public school's sourcebook for both moral and religious instruction. When struggles eventually arose over whose Bible to use and which doctrines to teach, William McGuffey, in 1836, offered the McGuffey Readers. McGuffey retained many favorite Biblical stories but added poems, exhortations and heroic tales. While children practiced their reading or arithmetic, they also learned lessons about honesty, love of neighbor, hard work, thriftiness, and courage (Lickona, 1997).

Another major force in the field of character education was the $18^{\text {th }}$ century philosopher, Immanuel Kant. Kant wrote about the duties and obligations of 
moral people. Kant believed that people should act in such a way that their actions become moral law. Kantian theory, later known as the Kantian Categorical Imperative, stated that each situation should be approached in the same manner, which would result in identical results, regardless of individual circumstances (Benninga, 1997).

The consensus supporting character education began to crumble. Darwin's introduction of evolution led people to see ideas, including morality, as being in discord with real-life issues and situations. No longer did society see issues as being black and white. Long-held beliefs about the real meaning of "truth" were questioned (Kohlberg, 1976).

In the $20^{\text {th }}$ century, the philosophy of logical positivism, transmitting from Europe to United States colleges and universities, asserted a basic distinction from facts (which could be scientifically proven) and values (which positivism held were mere expressions of feeling, not objective truth). As a result of positivism, morality was relativized and privatized, becoming a subject unfit for public debate or transmission through the schools. Consequently, public schools retreated from their once central role as moral and character educators.

The 1970s saw a return of value-laden education, but in new forms: values clarification and Kohlberg's (1976) moral dilemma discussions. Values clarification stressed not imposing values, but rather helping students choose their values freely. The teacher was urged to be only a facilitator of the process and, for fear of influencing students, was to withhold his or her own personal viewpoints. Whatever values the students determined were to be respected by the teacher and society. Kohlberg's theory helped develop students' powers of moral reasoning so they could judge which values were superior to others. Kohlberg posited that individuals proceed through a sequence of six distinct stages of moral reasoning. Each stage expands ethically in an attempt to reach a final, altruistic way of life. According to Kohlberg, as individuals moved through the sequence of moral reasoning, they become more apt to exhibit ethical behaviors in everyday life. By systematically exposing students to moral conflict accompanied by the presentation of moral reasoning one stage above their own, researchers believed that students would be attracted to that reasoning and adopt it as their own (Leming, 1997).

Aside from Kohlberg's structured levels of ethical reasoning, virtue ethics began to resurface in the 1990's as a valid basis of ethical reasoning. Here, in virtue ethics, an ethical person is one who contains good virtues, or character traits, such as honesty and integrity, and models those traits:

Statman (1997) indicates that becoming a good person is not just a matter of learning or applying principles, but includes imitation of models. People learn virtuousness the same way they learn to dance, cook, and play football. They learn it by watching competent people and trying to do the same. 
Based on this definition of virtue ethics, one can see a natural linkage between virtue ethics and character education programs. In character education programs, individuals serve as mentors to those attempting to further develop levels of character. These actions led to the formation of character education programs.

In 1992 the Josephson Institute of Ethics called together more than 30 educational leaders representing state school boards, teachers' unions, universities, ethnic centers, youth organizations and religious groups. The diverse group discussed how organizations might work together to help young people grow strong ethically. They agreed that a common language of values, used pervasively and consistently throughout a community, would be the most effective means of reaching young people. They found unanimous consensus in six essential ethical values (now known as the "Six Pillars of Character") that could be taught by public and private institutions without risk of socioeconomic, ethnic, political, gender or religious offense. These pillars are: trustworthiness, respect, responsibility, fairness, caring, and citizenship (Josephson Institute of Ethics, 2001b).

In Nebraska Character Counts! has been a prominent tool in shaping the moral development of youth, families, and their communities. To date:

- 1,900 youth and adults have been trained, equipping them to teach Character Counts! to others.

- 20,000 youth have been reached through Character Counts! programs involving at least 15 hours of programming.

- 123,000 youth have been reached through other Character Counts! programs including day camps, one-on-one contact with Kiwanis members, Family Community Education clubs, religious school classes, and employees participating in workforce training programs.

- Over 700,000 have been reached indirectly with information about character education through television and radio broadcasts; newspapers; newsletters provided to child care providers, 4-H members and parents of school children; and other media (Nebraska 4-H Department, 1999).

A recent survey of Nebraska educators demonstrated that Character Counts! has made a difference in the lives of students. Of those who responded:

- $85 \%$ reported an overall positive difference in the children they teach,

- $73 \%$ reported students using the language of the six pillars (trustworthiness, respect, responsibility, fairness, caring and citizenship), and 
- $75 \%$ reported changing their own behavior as a result of teaching Character Counts! (Nebraska 4-H Department, 1999).

Behaviors most frequently seen as changed due to using Character Counts! included:

- Helping each other (61\% reported increased frequency),

- Blaming others (55\% reported decreased frequency), and

- Being truthful (50\% reported increased frequency) (Nebraska State 4-H Department, 1999).

As unethical behaviors and violence continue to negatively influence life in the U.S., one can conclude that changes need to be made in an attempt to positively restructure the country's ethical systems. Increased character education is one alternative available to assist in remedying a declining moralistic society. Currently, research suggests a correlation between the character education of youth and positive ethical results throughout the United States. While these findings demonstrate positive changes experienced by youth audiences, to date, sparse research has been conducted on the effects of teaching character education programs on those individuals who implement the programs.

\section{Adult Learning Strategies}

To gain an appreciation for the problem at hand, it is also important to closely examine the learning strategies of adults. According to a University of Michigan study, individuals create their own new understandings, based upon the interactions of what they already know and believe, and the phenomena or ideas with which they come into contact (Richardson, 1999). This suggests that the internalization of concepts is a direct result of learning based on interactions and experiences.

When considering the moral upbringing of individuals, many feel that one's character is permanently formed during childhood. However, character education is, in fact, a lifelong process (Sprinthall \& Sprinthall, 1997). While one experiences real world situations, internal psychological processes are expanded, thus leading to the internalization of taught concepts. Internalization can be defined as the incorporation of values or patterns of culture within the self as conscious or subconscious guiding principles through learning or socialization (Krippendorff, 1995).

In the same sense, teaching character education programs (direct experience) leads to the internalization of ethical principles found directly in character education. Internalized ethical principles result in increased moral behavior (Rest, 1997). Hence, one would assume that those teaching character education are more 
likely to use the ethical principles and exhibit positive behaviors as a direct result of their teaching and implementation experiences.

A 2001 study by Harms and Fritz analyzed the internalization of character traits in the personal and professional lives of 53 Nebraska Cooperative Extension Staff. The study determined that Character Counts! had a major impact on Cooperative Extension staff. Professionally, 91\% were more likely to emphasize the importance of Character Counts! principles with Cooperative Extension colleagues throughout Nebraska, while 93\% were more likely to emphasize the importance of Character Counts! principles in Cooperative Extension programming efforts as a result of teaching Character Counts! (Harms \& Fritz, 2001).

Personally, 77\% of respondents were more aware of ethical dilemmas within their own personal lives as a result of teaching Character Counts!. In addition, 85\% were more likely to institute ethical choices amongst friends and family as a result of teaching Character Counts! (Harms \& Fritz, 2001).

\section{Statement of the Problem}

While the study by Harms and Fritz (2001) shed some light on the internalization of character principles by those teaching the program, further research was needed. The original study examined a homogenous sample (Nebraska Cooperative Extension Staff) when, in fact, the application and integration of character education is much broader than this audience. However, it is unclear if the internalization was similar in different contexts and periods of time. This study sought to address the research void by comparing degrees of internalization across two populations with varying years of character education training. The null hypothesis that was tested stated that there was no significant difference in the internalization of character traits between those teachers and Cooperative Extension Staff who took part in character education programs and those who did not.

\section{Objectives}

Specifically, this study analyzed the following:

1. Description of the sample (gender, age, position, years of involvement);

2. Extent of character education professional and program development activities;

3. Degree of internalization and behavioral change of character education; and

4. Comparison of character education items by position, age of participants, and years of involvement with character education.

\section{Limitations}

Because the respondents for this study were not randomly sampled from the population of those who have received character education training, the results 
were not generalizable to a population. Therefore, findings, conclusions, and recommendations were limited to study respondents.

\section{Method}

\section{Design of the Study}

Target audience members were chosen based on their involvement in implementing character education with various audiences. The target audience for this study consisted of Nebraska K-12 teachers and all Nebraska Cooperative Extension Educators and Assistants involved with character education that received character education training via the Nebraska Department of Education and/or Nebraska Cooperative Extension. Based on this target audience, 109 individuals responded to the online survey.

The instrument was designed to address the study question: character education behavioral change by program educators (Ebmeier, 2001). The Six Pillars of Character from Character Counts! and the eight characteristics listed in the Nebraska statutes were used to develop the items for the survey.

The instrument contained 44 items that were grouped in four areas: character education involvement, character education integration, personal character education analysis, and demographics. The character education involvement section was composed of six questions with four-point Likert scale responses. A five-point Likert scale response was used for the nine questions of the character education integration section. A Post-then-Pre design was the basis for 18 questions of the personal character education analysis section (Rockwell \& Kohn, 1989). According to Rockwell and Kohn (1989), a post-then-pre design identification of self-reported behavioral changes provides substantial evidence programmatic impact. To obtain information on the levels of character education implementation and demographic backgrounds of survey participants, multiple choice questions were utilized.

The instrument was tested for face validity with a panel of experts and was field tested by a group of eight secondary educators who were not in the study. Cronbach's alpha reliability tests were performed on the data, producing reliability coefficients of .80 (character education involvement), .95 (character education integration), and .93 (post-then-pre data).

An informed consent letter and survey were posted on the Internet. The population was notified of the study via e-mail on April 27, 2002. This e-mail contained a link directing participants to the survey site. The first page of the survey site consisted of the informed consent letter. Thus, participants were not able to complete the survey without first reading and agreeing to the conditions of the study set forth in the informed consent letter. By completing the survey on the second page, participants gave their consent to participate in this study. Follow-up 
reminder e-mails were sent to the study population on May 8, May 15, and May 22, 2002. MANOVA comparisons of responses over varying response groupings yielded no differences.

Survey results were entered into a Microsoft (C) Excel database for analysis in SPSS-PC. Means, frequencies, and standard deviations for all relevant items were run, and significance for the study was set at $\alpha=.05$. To minimize the risk of a Type I error in the post-then-pre section, an alpha level of .005 was adopted (Gravetter \& Wallnau, 2000). Paired T-test comparisons were also made to analyze post-then-pre responses. ANOVA comparisons were performed to determine any relationships between categorical responses (position, age, and years of involvement with character education).

Results of questions 17 and 18 were lost via data transfer, creating a limitation to this study. In addition, results of post-then-pre questions for 30 respondents were lost via data transfer, creating an additional limitation.

\section{Results}

\section{Description of Sample}

The study sample was composed of 109 individuals involved in character education, including 64 (59\%) teachers and 45 (41\%) Cooperative Extension staff. Of the 109 respondents, 91 (83\%) were female and 17 (16\%) were male. One respondent did not identify his/her gender. Thirty (28\%) were between the ages of 20-35, while 39 (36\%) fell in the 36-50 category. Forty (37\%) respondents were between the ages of 51-65. When considering respondents' years of involvement with character education, 23 (21\%) respondents were involved less than 2 years, 48 (44\%) were involved from 2-5 years, and 37 (34\%) were involved more than 5 years. One respondent did not identify years of involvement with character education.

\section{Degree of Internalization and Behavioral Change}

When analyzing the mean scores, character education involvement reinforced respondents' value systems quite a bit $(\mathrm{M}=1.47)$ (see Table 1$)$. In addition, involvement with character education made respondents somewhat $(\mathrm{M}=1.77)$ more aware of telling little white lies in daily life, while respondents were somewhat $(\mathrm{M}=1.61)$ more aware of treating others in the same manner they would like to be treated. Respondents were somewhat $(\mathrm{M}=2.01)$ more aware of laws, such as speeding and littering. When working with diverse populations, respondents found it somewhat $(\mathrm{M}=2.06)$ easier as a result of character education involvement. In addition, respondents increased their participation levels somewhat $(\mathrm{M}=2.18)$ in community-based activities as a result of character education involvement. 
Table 1. Personal Awareness of the Impact of Character Education

\section{Involvement}

\begin{tabular}{|c|c|c|c|c|c|c|}
\hline Statement $n=109$ & Quite a Bit & Somewhat & Very Little & Not at All & \multirow{2}{*}{$\mathbf{M}^{\mathbf{a}}$} & \multirow{2}{*}{ SD } \\
\hline Has your involvement with Character Education: & 1 & 2 & 3 & 4 & & \\
\hline Reinforced your value system? & $\begin{array}{c}64 \\
(58.7 \%)\end{array}$ & $\begin{array}{c}40 \\
(36.7 \%)\end{array}$ & $4 \quad(3.7 \%)$ & $1 \quad(0.9 \%)$ & 1.47 & 0.62 \\
\hline Made you more aware of "little white lies?" & $40(36.7 \%)$ & $56(51.4 \%)$ & $11(10.1 \%)$ & $2 \quad(1.8 \%)$ & 1.77 & 0.70 \\
\hline $\begin{array}{l}\text { Made you more aware of treating people the way you would } \\
\text { like to be treated? }\end{array}$ & $\begin{array}{c}52 \\
(47.7 \%)\end{array}$ & $\begin{array}{c}48 \\
(44.0 \%)\end{array}$ & $8 \quad(7.3 \%)$ & $1 \quad(0.9 \%)$ & 1.61 & 0.67 \\
\hline Made you more aware of laws (speeding, littering, etc.)? & $29(26.6 \%)$ & $57(52.3 \%)$ & $\begin{array}{c}16 \\
(14.7 \%)\end{array}$ & $\begin{array}{c}7 \\
(6.4 \%)\end{array}$ & 2.01 & 0.82 \\
\hline Helped you work easier with diverse populations? & $23(21.1 \%)$ & $58(53.2 \%)$ & $26(23.9 \%)$ & $\begin{array}{c}2 \\
(1.8 \%)\end{array}$ & 2.06 & 0.72 \\
\hline Increased your participation in community activities? ${ }^{\mathrm{b}}$ & $22(20.2 \%)$ & $51(46.8 \%)$ & $29(26.6 \%)$ & $6 \quad(5.5 \%)$ & 2.18 & 0.82 \\
\hline
\end{tabular}

${ }^{\mathrm{a}}$ Note: 1 to 1.49 = Quite a Bit; 1.50 to 2.49 = Somewhat; 2.50 to 3.49 = Very Little; 3.50 to 4 = Not at All.

${ }^{\mathrm{b}}$ One missing response.

Mean scores for all character education integration responses ranged from 3.76 to 4.41 (Agree category). Statements included: I am better able to win or lose gracefully (M=3.76); I am better able to respect the authority of others $(\mathrm{M}=3.89)$; I realize the importance of community $(\mathrm{M}=4.12)$; and I try to model character building behavior ( $\mathrm{M}=4.41)$ (see Table 2$)$. 
Table 2. Attitudinal Impact of Character Education Integration

\begin{tabular}{|c|c|c|c|c|c|c|c|}
\hline Statement $n=109$ & $\begin{array}{l}\text { Strongly } \\
\text { Disagree } \\
\end{array}$ & Disagree & Sometimes & Agree & $\begin{array}{c}\text { Strongly } \\
\text { Agree }\end{array}$ & \multirow{2}{*}{$\mathbf{M}^{\mathrm{a}}$} & \multirow{2}{*}{ SD } \\
\hline $\begin{array}{l}\text { As I integrate Character Education into my } \\
\text { teaching curricula: }\end{array}$ & 1 & 2 & 3 & 4 & 5 & & \\
\hline I am better able to win or lose gracefully. & $\begin{array}{c}4 \\
(3.7 \%)\end{array}$ & $\begin{array}{c}7 \\
(6.4 \%) \\
\end{array}$ & $24(22.0 \%)$ & $50(45.9 \%)$ & $24(22.0 \%)$ & 3.76 & 0.99 \\
\hline $\begin{array}{l}\text { I am better able to think about the } \\
\text { consequences of my conduct before I act. }\end{array}$ & $\begin{array}{c}6 \\
(5.6 \%)\end{array}$ & $\begin{array}{c}4 \\
(3.7 \%)\end{array}$ & $17(15.7 \%)$ & $52(48.1 \%)$ & $29(26.9 \%)$ & 3.87 & 1.03 \\
\hline $\begin{array}{l}\text { I am more concerned about finding a solution } \\
\text { rather than identifying the fault. }\end{array}$ & $\begin{array}{c}4 \\
(3.7 \%)\end{array}$ & $\begin{array}{c}3 \\
(2.8 \%)\end{array}$ & $\begin{array}{c}21 \\
(19.3 \%)\end{array}$ & $\begin{array}{c}56 \\
(51.4 \%)\end{array}$ & $\begin{array}{c}25 \\
(22.9 \%)\end{array}$ & 3.87 & 0.92 \\
\hline $\begin{array}{l}\text { I am better able to respect the authority of } \\
\text { others. }{ }^{c}\end{array}$ & $\begin{array}{c}3 \\
(2.8 \%) \\
\end{array}$ & $7 \quad(6.5 \%)$ & $19(17.8 \%)$ & $48(44.9 \%)$ & $30(28.0 \%)$ & 3.89 & 0.98 \\
\hline $\begin{array}{l}\text { I am more likely to take personal } \\
\text { responsibility for my actions. }{ }^{\text {b }}\end{array}$ & $5 \quad(4.6 \%)$ & $\begin{array}{c}4 \\
(3.7 \%)\end{array}$ & $10(9.3 \%)$ & $54(50.0 \%)$ & $35(32.4 \%)$ & 4.02 & 1.00 \\
\hline I realize the importance of the community. & $\begin{array}{c}5 \\
(4.6 \%) \\
\end{array}$ & $4 \quad(3.7 \%)$ & $\begin{array}{c}5 \\
(4.6 \%)\end{array}$ & $54(49.5 \%)$ & $41(37.6 \%)$ & 4.12 & 0.99 \\
\hline $\begin{array}{l}\text { Treating public property with care is } \\
\text { important to me. }\end{array}$ & $\begin{array}{c}5 \\
(4.6 \%)\end{array}$ & $\begin{array}{c}3 \\
(2.8 \%)\end{array}$ & $\begin{array}{c}5 \\
(4.6 \%)\end{array}$ & $39(36.1 \%)$ & $56(51.9 \%)$ & 4.28 & 1.01 \\
\hline $\begin{array}{l}\text { I realize the importance of standing up for } \\
\text { what is morally right. }\end{array}$ & $\begin{array}{c}6 \\
(5.5 \%) \\
\end{array}$ & $\begin{array}{c}3 \\
(2.8 \%)\end{array}$ & $\begin{array}{c}1 \\
(0.9 \%)\end{array}$ & $40(36.7 \%)$ & $59(54.1 \%)$ & 4.31 & 1.03 \\
\hline I try to model character building behavior. ${ }^{c}$ & $(4.7 \%)$ & $\begin{array}{c}2 \\
(1.9 \%)\end{array}$ & $\begin{array}{c}2 \\
(1.9 \%)\end{array}$ & $33(30.8 \%)$ & $65(60.7 \%)$ & 4.41 & 0.98 \\
\hline
\end{tabular}

${ }^{\mathrm{a}}$ Note: 1 to 1.49 = Strongly Disagree; 1.50 to 2.49 = Disagree; 2.50 to 3.49 = Sometimes; 3.50 to $4.49=$ Agree; 4.50 to 5 = Strongly Agree.

${ }^{\mathrm{b}}$ One missing response.

${ }^{\mathrm{C}}$ Two missing responses.

Paired T-test comparisons of post-then-pre responses to general behaviors exhibiting character indicates involvement in character education programs was significantly effective $(\mathrm{p}=.005)$ in producing positive behavioral changes. Thus the null hypothesis was rejected. Specific behaviors found to be influenced as a result of participation in character education programs include:

- Considering other peoples' feelings

- Valuing people for who they are

- Resolving conflict in a peaceful manner

- Using a plan of action for making tough decisions

- Being self-discipline

- Admitting when a mistake is made

- Including everyone in activities 
- Informing the cashier when given too much change

- Voting

- Seeing both sides of the story when opinions differ

- Apologizing

- Listening carefully and not interrupting others

- Winning and losing gracefully

- Standing at attention for the Pledge of Allegiance and the National Anthem

- Being dependable

- Keeping promises

- Considering others' feelings

- Respecting others' opinions (see Table 3) 
Table 3. Paired T-test Results of Character Education Pre-Post Statements

\begin{tabular}{|c|c|c|c|c|c|c|}
\hline \multicolumn{2}{|l|}{ Statement } & $\mathbf{n}$ & $\mathbf{M}^{\mathbf{a}}$ & SD & t statistic & Prob. \\
\hline \multirow{2}{*}{ I try to consider other peoples' feelings as I interact with them. } & POST & \multirow{2}{*}{84} & 4.54 & 0.5 & \multirow{2}{*}{4.12} & \multirow{2}{*}{$0.000^{*}$} \\
\hline & PRE & & 4.27 & 0.7 & & \\
\hline \multirow{2}{*}{ I try to value people for who they are, not for what they can do for me. } & POST & \multirow{2}{*}{83} & 4.52 & 0.6 & \multirow{2}{*}{3.78} & \multirow{2}{*}{$0.000^{*}$} \\
\hline & PRE & & 4.24 & 0.8 & & \\
\hline \multirow[b]{2}{*}{ I try to resolve conflict in a peaceful manner. } & POST & \multirow[b]{2}{*}{85} & 4.52 & 0.6 & \multirow[b]{2}{*}{3.96} & \multirow[b]{2}{*}{$0.000^{*}$} \\
\hline & PRE & & 4.29 & 0.8 & & \\
\hline \multirow{2}{*}{ I use a plan of action for making tough decisions. } & POST & \multirow{2}{*}{84} & 4.07 & 0.8 & \multirow{2}{*}{5.12} & \multirow{2}{*}{$0.000^{*}$} \\
\hline & PRE & & 3.65 & 0.9 & & \\
\hline \multirow{2}{*}{ I am self-disciplined. } & POST & \multirow[b]{2}{*}{82} & 4.38 & 0.7 & \multirow{2}{*}{2.89} & \multirow{2}{*}{$0.000^{*}$} \\
\hline & PRE & & 4.15 & 0.7 & & \\
\hline \multirow{2}{*}{ I admit when I make a mistake. } & POST & \multirow{2}{*}{83} & 4.27 & 0.6 & \multirow{2}{*}{4.28} & \multirow{2}{*}{$0.000^{*}$} \\
\hline & PRE & & 3.98 & 0.7 & & \\
\hline \multirow{2}{*}{$\begin{array}{l}\text { I make an effort to create an atmosphere that includes everyone in whatever I } \\
\text { am doing. }\end{array}$} & POST & \multirow{2}{*}{84} & 4.44 & 0.8 & \multirow{2}{*}{2.4} & \multirow{2}{*}{$0.000^{*}$} \\
\hline & PRE & & 4.29 & 0.9 & & \\
\hline 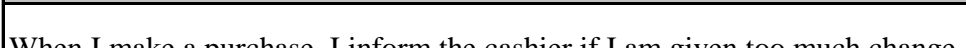 & POST & 81 & 4.51 & 0.7 & & \\
\hline When 1 make a purchase, 1 inform the casnier if 1 am given too much change. & PRE & 84 & 4.42 & 0.8 & 2.19 & $0.000^{\top}$ \\
\hline & POST & & 4.47 & 0.6 & & \\
\hline I vote to participate in the public decision making process. & PRE & 83 & 4.18 & 0.7 & 4.28 & 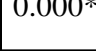 \\
\hline & POST & & 4.54 & 0.7 & & \\
\hline When opinions differ, I try to see both sides of the story. & PRE & 80 & 4.41 & 0.7 & 2 & $0.000^{*}$ \\
\hline I onoloxizo whon J'ue caid or done comothing to burt somono & POST & $92+2-3$ & 4.12 & 0.7 & 560 & $0 \Omega 0 \cap *$ * \\
\hline 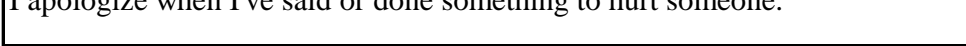 & PRE & OJ & 3.75 & 0.8 & 0.00 & 0.000 \\
\hline 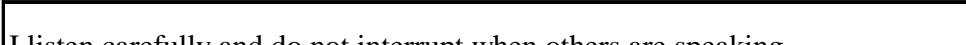 & POST & 94 & 4.6 & 0.6 & 221 & O $0000 *$ * \\
\hline 1 issten careruny and do not interrupt wnen otners are speaking. & PRE & 04 & 4.43 & 0.6 & 3.31 & $0.000^{2}$ \\
\hline & POST & & 4.87 & 0.3 & 107 & 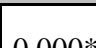 \\
\hline Winning and losing gracefully are character traits 1 admire. & PRE & 83 & 4.81 & 0.4 & 1.92 & 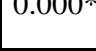 \\
\hline & POST & & 4.77 & 0.4 & & \\
\hline 1 stand at attention for the Pledge of Allegiance and the National Anthem. & PRE & 83 & 4.59 & 0.6 & 3.49 & $0.000^{*}$ \\
\hline & POST & & 4.55 & 0.6 & & \\
\hline Others can depend on me to complete what I have promised to do. & PRE & 83 & 4.22 & 0.7 & 4.17 & $0.001^{*}$ \\
\hline I molo on offort to loon promicos oyon whon it ic difficult & POST & 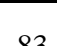 & 4.29 & 0.7 & 12 & O $000 *$ \\
\hline 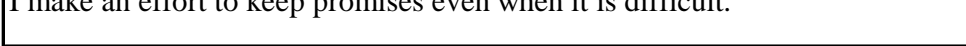 & PRE & 03 & 3.96 & 0.8 & 4.13 & $0.000^{\circ}$ \\
\hline
\end{tabular}

${ }^{\mathrm{a}}$ Note: 1 to 1.49 = Almost Never; 1.50 to 2.49 = Rarely; 2.50 to 3.49 = Sometimes; 3.50 to 4.49 = Frequently; 4.50 to 5 = Almost Always.

${ }^{*} \mathrm{p}<.005$ to minimize the risk of Type I Error. 


\section{Comparison of Character Education Items by Position, Age, and Years of Involvement with Character Education}

When making ANOVA comparisons between attitudinal impact of character education integration and position, comparisons were run on teachers and Cooperative Extension staff only. No significance was found when comparing attitudinal impact of character education integration by teachers and Extension staff.

ANOVA comparisons between personal awareness of character education involvement and age yielded no significant difference. In addition, ANOVA comparisons between attitudinal impact of character education integration and age yielded no significant difference.

ANOVA comparisons between personal awareness of character education involvement and age indicated a significant difference (df 1, F Value=11.58, $\mathrm{p}=.001$ ) between teachers and Cooperative Extension staff responses to the question "Has your involvement with Character Education helped you work easier with diverse populations?” There was a -0.47 mean difference between teachers and Cooperative Extension Staff, with teachers being able to work somewhat easier with diverse audiences ( $\mathrm{M}=1.92, \mathrm{SD} .67)$ as a result of character education involvement when compared to Cooperative Extension staff ( $M=2.39$, SD .77).

ANOVA comparisons between personal awareness of character education involvement and years of experience with character education yielded no significant difference.

ANOVA comparisons between attitudinal impact of character education integration and years of involvement with character education resulted in one significant difference. A Tukey HSD follow-up indicated the difference was between those respondents involved with character education for less than two years and respondents involved with character education for five years or more, and "As I integrate Character Education more and more into my teaching curricula, I try to model character building behavior.” There was a -0.49 mean difference between respondents involved with character education for five years or more and respondents involved with character education for less than two years. Those individuals involved with character education for a longer period of time focus more (M=4.60, SD 0.88) at modeling character building behavior than those respondents involved with character education for a lesser period of time $(\mathrm{M}=4.10, \mathrm{SD} 1.08)$.

\section{Conclusions and Recommendations}

In this study, the female respondents outnumbered male respondents five to one. This mix is congruent with a previous character education study by Harms and Fritz (2001). 
Mean scores for personal awareness and attitudinal impacts of character involvement and integration data showed positive attitudinal and behavioral changes as a result of character education involvement and integration. These results support conclusions from research by Sprinthall and Sprinthall (1997) that character education is a lifelong process, continuously strengthened by real-life situations.

Teachers and Cooperative Extension Staff in this study perceive they are internalizing character traits and improving their own character behavior. This is congruent with research by Rest (1997). Additionally, this research suggests the longer someone has been involved in character education, the more likely they are to model character building behavior. This supports the Sprinthall and Sprinthall's theory (1997) that people continue to learn throughout their lifetime and can modify their behaviors.

Although still in the "somewhat" range, teachers in this study reported working with diverse populations as easier for them than Cooperative Extension staff. This may be attributed to teachers' continuous awareness of diverse audiences needs through required human relations training courses, as required by the Nebraska Department of Education (2000). While Cooperative Extension is continuously broadening their focus to include more diverse audiences, it is unclear whether similar training is mandated.

Increased ongoing and intensive multicultural training is recommended to assist Extension staff when dealing with diverse audiences. This training may have programming implications beyond character education.

While collecting this self-reported data provides the character education field with information about respondents' character education behaviors and internalization, it may give only a one-dimensional view. Researchers are encouraged to strengthen subsequent research by including reporting of co-workers, supervisors, and peers of respondents.

\section{References}

Benninga, J. S. (1997). Schools, character development, and citizenship. In A. Molnar, (Ed.), The construction of children's character: Ninety-six yearbook of the National Society for the Study of Education. (pp. 77-96). Chicago: University of Chicago Press.

Boyer, E. L. (1995). The basic school: A community for learning. Princeton: The Carnegie Foundation for the Advancement of Teaching.

The Center for the $4^{\text {th }}$ and $5^{\text {th }}$ Rs (2002). The Center for the $4^{\text {th }}$ and $5^{\text {th }}$ Rs: Respect and responsibility. Retrieved on October 31, 2004, from http://www.cortland.edu/c4n5rs/brochure.htm. 
Ebmeier, S. (2001). Nebraska partnership in character education. Unpublished instrument.

Gravetter, F., \& Wallnau, L. (2000). Statistics for the behavioral sciences. Belmont, CA: Wadsworth.

Harms, K., \& Fritz, S. (2001, December). Internalization of character traits by those who teach Character Counts!. Journal of Extension, 39. Retrieved October 31, 2004, from http://www.joe.org/joe/2001december/a4.html.

Josephson Institute of Ethics. (2001a). The ethics of A merican youth violence and substance abuse: Press release. Retrieved October 31, 2004, from http://www.josephsoninstitute.org/Survey2000/violence2000-pressrelease.htm.

Josephson Institute of Ethics. (2001b). About CHARACTER COUNTS!. Retrieved October 31, 2004, from http://www.charactercounts.org/about.htm.

Krippendorff, K. (1995). Internalization. In F. Heylighen, C. Joslyn and V. Turchin (Eds.), Principia cybernetica web (Principia cybernsetica, Brussels). Retrieved on October 31, 2004, from http://pespmc1.vub.ac.be/asc/Internaliza.html.

Kohlberg, L. (1976). Moral stages and moralization: The cognitive-developmental approach. In T. Lickona (ed.), Moral development and behavior: Theory, research, and social issues. (pp. 34-35). International Thomson Publishing.

Leming, J. S. (1997). Research and practice in character education: A historical perspective. In A. Molnar, (ed.), The construction of children's character: Ninetysix yearbook of the National Society for the Study of Education. (pp. 31-44).

Chicago: University of Chicago Press.

Lickona, T. (1997). Traditionalist views of character and character education. In A. Molnar, (Ed.), The construction of children's character: Ninety-six yearbook of the National Society for the Study of Education. (pp. 45-62). Chicago: University of Chicago Press.

Nebraska Department of Education. (2002). Nebraska character education guidelines. Unpublished manuscript, Nebraska Department of Education.

Nebraska Department of Education. (2000). Rule 21: Regulations for the issuance of certificates and permits to teach, counsel, supervise, and administer in Nebraska Schools. Retrieved on October 31, 2004, from http://www.nde.state.ne.us/LEGAL/RULE21.HTML. 
Nebraska State 4-H Department. (1999). Character Counts! Character Counts! 1998 Summary. Unpublished manuscript, University of Nebraska Cooperative Extension Division.

Rest, J. (1997). Can ethics be taught to adults? In M. Josephson (Ed.), Character Counts! Character development seminars. (pp. 52-55). CA: Josephson Institute.

Richardson, V. (1999). Teacher education and the construction of meaning. In G. Griffin (Ed.), The education of teachers. (pp. 145-166). Chicago: National Society for the Study of Education.

Rockwell, K., \& Kohn, H. (1989). Post-Then-Pre Evaluation. Journal of Extension, 27. Retrieved on October 31, 2004, from http://www.joe.org/joe/1989summer/a5.html.

Sprinthall, N., \& Sprintall, L. T. (1997). How to raise a good child. In M. Josephson (Ed.), Character Counts! Character development seminars. (pp. 6770). CA: Josephson Institute.

Statman, D. (1997). Virtue ethics: A critical reader. Washington, D.C.: Georgetown University Press. 